\title{
GUGATAN WARGA NEGARA (CITIZEN LAW SUIT) DAN JUSTICIABILITY PEMENUHAN HAK ATAS LINGKUNGAN HIDUP YANG BAIK DAN SEHAT
}

Oleh :

Yustina Niken Sharaningtyas ${ }^{1}$

Fakultas Hukum Universitas Atma Jaya Yogyakarta

\begin{abstract}
Abstrak
Kajian ini bertujuan untuk mengkaitkan model gugatan warga negara (citizen law suit) dan justiciability dalam pemenuhan hak atas lingkungan hidup yang baik dan sehat. Kebakaran hutan dan lahan yang melanda Indonesia di tahun 2015 membawa dampak buruk yang luar biasa bagi para warga. Citizen law suit merupakan model gugatan yang tepat untuk menuntut Pemerintah untuk mengevaluasi dan memperbaiki segala upaya dan kebijakan untuk mengatasi permasalahan kebakaran hutan serta lahan. Citizen Law Suit merupakan sarana justiciability dalam pemenuhan hak warga atas lingkungan hidup yang baik dan sehat.
\end{abstract}

Kata Kunci: Citizen Law Suit, Justiciability, Hak atas Lingkungan yang Baik dan Sehat

\section{Abstract}

This paper aims to link the model of citizen law suit and the justiciability of the fulfillment of the right to a clean and healthy environment. Land and forest fires that hit Indonesia in 2015 brought tremendous adverse impact for the citizens. The citizen lawsuit is a lawsuit model that is proper to be used to demand the Government to evaluate and to improve all efforts and policies to solve the problem of the land and forest fires. Citizen Law Suit is a justiciability means to fulfill of the citizen's right to a clean and healthy environment.

Keywords: Citizen Law Suit, Justiciability, Right to a Clean and Healthy Environment

\section{Pendahuluan}

\section{Latar belakang}

Salah satu tujuan negara Republik Indonesia sebagaimana termaktub di dalam Alinea IV Pembukaan Undang-Undang Dasar Negara Republik Indonesia Tahun 1945 (UUD NRI Tahun 1945) adalah untuk membentuk suatu pemerintah negara Indonesia yang melindungi segenap bangsa Indonesia dan seluruh tumpah darah Indonesia. Dalam mewujudkan tujuan tersebut, negara Indonesia berlandaskan pada prinsip-prinsip yang dijadikan pilar dalam penyelenggaraan negara. Salah satunya adalah prinsip negara hukum sebagaimana tertuang di dalam Pasal 1 ayat (3) UUD NRI Tahun 1945yang menyatakan: "Negara Indonesia adalah Negara Hukum". Selanjutnya, Pasal 1 ayat (2) UUD NRI Tahun 1945 menegaskan bahwa "Kedaulatan berada di tangan rakyat dan dilaksanakan menurut Undang-Undang Dasar”, yang bermakna kedaulatan berada di tangan rakyat dan segala tindakan yang dijalankan ataupun diputuskan oleh alat kelengkapan negara dan masyarakat harus didasarkan pada aturan hukum. ${ }^{2}$

\footnotetext{
${ }^{1}$ Yustina Niken Saraningtyas adalah dosen di Fakultas Hukum Universitas Atmajaya Yogyakarta.
}

${ }^{2}$ Kedaulatan berada ditangan rakyat dapat diartikan sebagai demokrasi, akan tetapi demokrasi yang konstitusional (constitutional democracy), yaitu demokrasi yang berdasarkan oleh hukum. Lihat Jimly Asshiddiqie. 2010. Green Constitution. Jakarta: Rajawali Pers, h. 108. Hal ini sejalan juga dengan pendapat yang dikemukakan oleh Krabe bahwa negara sebagai pencipta dan 


\section{KERTHA PATRIKA}

Volume 38, Nomor 1, Januari-April 2016

Dalam prinsip negara hukum ini, Aristoteles mengemukakan pemikiran bahwa yang memerintah dalam negara bukanlah manusia melainkan pikiran yang adil dan kesusilaanlah yang menentukan baik buruknya suatu hukum. ${ }^{3}$ Hukum merupakan suatu kesatuan sistem bernegara. Sesungguhnya, pemegang kekuasaan tertinggi dalam suatu negara adalah hukum, bukan tercermin pada pribadi atau orang. Konsep negara hukum menghendaki adanya unsur-unsur tertentu dalam penyelenggaraan sistem ketatanegaraan, yang terutama yaitu adanya jaminan hak asasi manusia (HAM). Sejatinya negara terbentuk karena adanya kontrak sosial. Dari kontrak sosial inilah individu-individu dalam ikatan kehidupan bersama dalam negara menyerahkan hak-hak politik dan sosialnya kepada komunitas negara, sehingga negara harus memberikan jaminan kepada hak-hak yang melekat di dalam individu-individu maupun di dalam ikatan kehidupan kemasyarakatan. ${ }^{4}$

Sebagai bagian dari HAM, rakyat Indonesia mempunyai hak untuk mendapatkan lingkungan yang baik dan sehat serta berhak mendapatkan pelayanan kesehatan, seperti yang diatur dalam Pasal 28 H ayat (1) UUD NRI Tahun 1945 yang menyatakan: Setiap orang berhak hidup sejahtera lahir dan batin, bertempat tinggal, dan mendapatkan lingkungan hidup yang baik dan sehat serta berhak memperoleh pelayanan kesehatan". Manusia dan lingkungan merupakan suatu kesatuan yang saling mempengaruhi seperti yang tercantum dalam Pasal 1 UndangUndang Nomor 32 Tahun 2009 tentang Perlindungan dan Pengelolaan Lingkungan Hidup (UU Perlindungan dan Pengelolaan Lingkungan Hidup) menyatakan: "Lingkungan hidup adalah kesatuan ruang dengan semua benda, daya, keadaan, dan makhluk hidup, termasuk manusia dan perilakunya, yang mempengaruhi alam itu sendiri, kelangsungan perikehidupan, dan kesejahteraan manusia serta makhluk hidup lain".

Lebih lanjut, penegasan tentang perlindungan akan udara yang sehat bagi rakyat adalah diatur dalam Pasal 3 huruf $b$ “...menjamin keselamatan, kesehatan, dan kehidupan manusia”. Hal senada juga diatur dalam Pasal 9 ayat (3) Undang-Undang Nomor 39 Tahun 1999 tentang Hak Asasi Manusia (UU HAM) yang menyatakan: setiap orang berhak atas lingkungan hidup yang baik dan sehat". Lebih jelasnya dalam UU HAM, semua perlindungan itu dibebankan kepada pemerintah, seperti yang termuat dalam Pasal 8 yang menyatakan "Perlindungan, pemajuan, penegakan, dan pemenuhan hak asasi manusia terutama menjadi tanggung jawab Pemerintah".

Seharusnya, dengan peraturan perundang-undangan yang sudah ada, pemerintah dapat merencanakan, mengatur bahkan mewujudkan jaminan perlindungan kepada warga atas lingkungan hidup yang baik dan sehat. Terlepas dari apakah semua peraturan perundang-undangan tersebut efektif melindungi hak-hak warga. Faktanya tidak demikian, selama berbulan-bulan di tahun 2015 yang lalu, berbagai daerah di Indonesia mengalami dampak atas terjadinya keba-

penegak hukum di dalam segala kegiatannya harus tunduk pada hukum yang berlaku.Ini berarti hukum membawahkan negara. Berdasarkan pengertian hukum itu bersumber dari kesadaran hukum rakyat, maka hukum mempunyai wibawa yang tidak berkaitan dengan seseorang (impersonal). Lihat Usep Ranawijaya,1983. Hukum Tata Negara:Dasar-Dasarnya. Jakarta: Ghalia Indonesia, h. 181 .

${ }^{3}$ Mukthie Fadjar. 2004. Tipe Negara Hukum. Malang:Bayu Media,h.19.

${ }^{4}$ Hestu Cipto Handoyo. 2015. Hukum Tata Negara Indonesia. Yogyakarta: Cahaya Atma Pustaka, h.17. 
karan hutan dan lahan di berbagai wilayah tanah air. Kebakaran hutan dan lahan yang berkepanjangan menghasilkan kabut asap yang berdampak dalam segi kehidupan manusia. Kabut asap dapat dikatakan merupakan hasil kejahatan lingkungan luar biasa, yang telah merampas hak asasi manusia untuk memperoleh udara segar. Akibat asap, ribuan warga Indonesia mengalami kerugian materil maupun fisik, baik itu kesehatan, pendidikan maupun perekonomian. ${ }^{5}$

Pembentukan posko-posko pengaduan dampak kabut asap di berbagai daerah menunjukkan bahwa saat ini kondisi masyarakat telah berubah dan berkembang. Dalam perkembangannya masyarakat semakin rasional menilai kinerja dan kebijakan pemerintah. Bahkan masyarakat dapat mengintervensi pemerintah untuk mempengaruhi kebijakan yang ada. Warga di beberapa daerah merencanakan untuk mengajukan citizen law suit kepada pemerintah yang dinilai lalai untuk mengatasi kabut asap.

Landasan hukum citizen law suit tidaklah dikenal di Indonesia. Namun langkah ini ditempuh oleh warga sebagai metode alternatif untuk menuntut pemenuhan tanggung jawab pemerintah atas lingkungan hidup yang baik dan sehat. Hak atas lingkungan hidup yang baik dan sehat merupakan bagian dari hak asasi atas ekonomi, sosial dan budaya. Negara memiliki kewajiban untuk mengupayakan langkah-langkah yang terencana, konkrit dan komprehensif dalam memenuhi hak-hak ekonomi, sosial, budaya (hak ekosob) warga negaranya.

Hal ini tidak terlepas dari isu justiciability ${ }^{6}$ dan penegakan (enforceability) hak ekosob menjadi penting tatkala menguji apakah hak-hak ini telah menjadi hak hukum yang dapat diajukan klaim apabila terdapat kegagalan negara dalam pemenuhan hak ekosob atau kegagalan negara memenuhi obligasinya/kewajibannya, yang dimuat dalam norma dan standar hukum internasional dan domestik. Negara mempunyai kewajiban untuk mengupayakan langkah-langkah yang tepat dalam pemenuhan hak ekosob. Di awal perkembangannya, terjadi perdebatan mengenai pemenuhan hak ekosob sebagai hak hukum. Pemenuhan hak ekosob bergantung pada alokasi sumber daya dan kebijakan pemerintah. Hal tersebut dijadikan dasar argumen bahwa hak ekosob tidak dapat dipaksakan untuk diputuskan pemenuhannya lewat pengadilan atau melalui vonis hakim. ${ }^{7}$

${ }^{5}$ Akibat dari kabut asap yang menyeimuti berbagai wilayah di tanah air, setidaknya ada sekitar 425.000 warga yang terjangkit penyakit ISPA (Infeksi Saluran Pernafasan). Lihat http://nasional.tempo.co/read/news/2015/10/17/206710325/dampakkabut-asap-ispa-jangkiti-425-ribu-jiwa-di-7-provinsi. Akibat kabut asap, aktifitas ekonomi tidak berjalan lancar, sekolah diliburkan, segala aktifitas warga terganggu dan kerugian materiil diduga mencapai 200 triliun. Lihat juga http://www.bbc.com/indonesia/ berita_indonesia/2015/10/151026_indonesiakabutasap.

${ }^{6}$ Justiaciability is the quality ofbeing appropriate for review by a court, Bryan A. Garner, et.al (ed), 1999,Black's Law Dictionary, St. Paul, West Publishing Co., 1999, h. 870. Justiciability didefinisikan sebagai kualitas (sebuah isu) untuk dapat diperiksa oleh sebuah lembaga peradilan. Justiciability belum ada kata padanan resminya dalam Kamus Besar Bahasa Indonesia. Maka, Penulis sengaja tidak mencari padanan kata justiciability dalam Bahasa Indonesia demi akurasi terminologi kata. Walaupun dalam beberapa artikel, justiciability sering dipadankan dengan istilah kata justisiabilitas Penulis sengaja tidak mencari padanan istilah justiciability dalam bahasa Indonesia terkait dengan kepentingan akurasi terminologi

${ }^{7}$ Lihat "Key Concepts on ESCRs: Can Economic, Social and Cultural Rights be Litigated at Courts?” dalam http://www. ohchr.org/EN/Issues/ESCR/Pages/CanESCRbelitigatedatcourts.aspx. Lihat juga Shivani Verma.“Justiciability of Economic Social and Cultural Rights (Relevant Case Law)"Makalah disampaikan dalam The International Council on Human Rights Policy Review Meeting di Geneva, tanggal 15 Maret 2005.Terkait dengan bagaimana perbandingan pemenuhan hak ekosob dengan beberapa contoh kasus dapat dibaca di International Commision of Jurist (ICJ).2008. Courts and the Legal Enforcement of Economic, Social and Cultural Rights: Comparative Experiences of Justiciability. Geneva:ICJ. 


\section{KERTHA PATRIKA}

Volume 38, Nomor 1, Januari-April 2016

Pada ranah internasional, Universal Declaration of Human Rights (Deklarasi Universal Hak-Hak Asasi Manusia/DUHAM) yang diadopsi oleh the United Nations General Assembly (Majelis Umum Perserikatan Bangsa Bangsa) pada tahun 1948 telah memuat hak ekosob. Hakhak tersebut semakin mendapatkan penegasan sebagai norma internasional pada tahun 1966 melalui International Covenant on Economic, Social and Cultural Rights (Kovenan Internasional tentang Hak-hak Ekonomi, Sosial dan Budaya). Kovenan ini menjadi rujukan bagi komunitas internasional dalam mempromosikan hak ekosob, termasuk Indonesia yang telah meratifikasinya melalui Undang-Undang Nomor 11 Tahun 2005.

\section{Rumusan Masalah}

Berlandaskan pada persoalan yang telah dikemukakan di atas, artikel ini menyajikan kajian mengenai citizen law suit dan justiacialibility hak atas lingkungan hidup yang baik dan sehat yang merupakan bagian dari hak ekosob. Sampai saat ini belum ada peraturan perundangan mengenai mekanisme citizen law suit di Indonesia. Di sisi lain terkait dengan hak asasi manusia, justiciability terhadap hak ekosob masih menyisakan pro dan kontra, apakah hak ekosob dapat dituntut pemenuhannya melalui mekanisme pengadilan. Oleh karena itu, dalam artikel ini penulis akan menganalisis mengenai apakah citizen law suit dapat diajukan sebagai alternatif sarana justiciability hak atas lingkungan hidup yang baik dan sehat di Indonesia.

\section{Pembahasan}

\section{Citizen Law Suit: Teori dan Praktek yang berkembang di Indonesia}

Beberapa referensi menyatakan bahwa hak gugat warga Negara (Citizen Law Suit) telah lama berkembang hanya di negara-negara yang menganut sistem Common Law. Karakteristik utama yang membedakan antara sistem Common Law dan Civil Law adalah dalam sistem Common Law, yurisprudensi dijadikan sebagai sumber hukum utama, menganut doktrin stare decisis, ${ }^{8}$ dan adanya adversary system ${ }^{9}$ dalam proses peradilan. Berbeda halnya dalam sistem hukum Civil Law yang mengenal adanya kodifikasi, undang-undang sebagai sumber hukum utama, dan sistem peradilannya bersifat inkuisitoral. ${ }^{10}$ Dengan pembedaan karakteristik tersebut, maka beberapa pakar menyimpulkan bahwa citizen law suit tidak diterapkan di negara yang menganut sistem hukum Civil Law dengan dalih untuk menjamin kepastian hukum. Hal ini tentu perlu ditelaah lebih lanjut, apakah memang demikian bahwa citizen law suit hanya dianut oleh negara-negara yang bersistem Common Law.

${ }^{8}$ Stare decisis adalah presedenatau suatu prinsip hukum menurut tradisi Common Law, dalam hal mana suatu pengadilan yang menghadapi masalah tertentu akan menerapkan atau mengikuti keputusan pengadilan sebelumnya yang memuat masalah hukum yang sama dengan yang dihadapi oleh pengadilan tersebut.

${ }^{9}$ Adversary system merupakan sistem yang umumnya berlaku di negara yang menganut Common Law. Sistem ini menempatkan hakim sebagai wasit yang tidak berpihak dan menjaga supaya para pihak dan pengacaranya bertindak sesuai prosedur pengadilan. Kemudian hakim memutuskan perkara berdasarkan bukti-bukti yang dikemukakan oleh para pihak dan hukum yang berlaku.

${ }^{10}$ Inkuisitorial maksudnya bahwa dalam sistem itu, hakim mempunyai peranan besar dalam mengarahkan dan memutuskan perkara. Hakim aktif dalam menemukan fakta dan cermat dalam menilai alat bukti.

34 | Jurnal Ilmiah Fakultas Hukum Universitas Udayana 
Dalam sistem Common Law, prinsip citizen law suit sama dengan prinsip actio popularis, misalnya dalam gugatan terhadap perlindungan lingkungan oleh warga negara, terlepas apakah warga negara tersebut mengalami langsung pencemarannya atau tidak. Oleh karena masalah perlindungan lingkungan merupakan kepentingan umum atau kepentingan masyarakat luas, maka setiap warga negara berhak menuntutnya. ${ }^{11}$ Secara sederhana, Actio popularis merupakan sebuah prosedur pengajuan gugatan yang melibatkan kepentingan umum secara perwakilan. Gugatan dapat ditempuh dengan acuan bahwa setiap warga negara tanpa kecuali mempunyai hak membela kepentingan umum.

Citizen law suit berkembang pula di berbagai negara yang telah mempraktekkannya dalam beberapa kasus, khususnya di bidang lingkungan hidup seperti di Amerika Serikat, India, dan Australia, khususnya di bidang lingkungan hidup. Di Amerika Serikat, hak gugat ini diperkenalkan dalam Clean Air Act (article 304), The Endangered Species Act (1973), dan dalam Resource Conservation and Recovery Act (1976). ${ }^{12}$ Seorang Warga Negara Amerika Serikat pernah menggugat pemerintahnya atas kelalaian Pemerintah dalam melakukan pelestarian terhadap spesies kelelawar langka. Gugatan tersebut dikabulkan dan pemerintah Amerika Serikat kemudian mengeluarkan undang-undang tentang konservasi kelelawar langka. ${ }^{13}$ Di India, seorang Warga Negara India mengajukan gugatan atas kelalaian Pemerintah India dalam melestarikan Sungai Gangga yang merupakan sungai suci bagi umat Hindu. ${ }^{14}$ Implikasinya adalah dikeluarkannya peraturan mengenai larangan pemerintah India kepada pabrik-pabrik di sekitar sungai Gangga untuk melakukan pencemaran terhadap sungai. ${ }^{15}$ Dari kasus-kasus tersebut dapat disimpulkan bahwa citizen law suit merupakan akses orang perorangan warganegara untuk kepentingan keseluruhan warganegara atau kepentingan publik dengan mengajukan gugatan di pengadilan guna menuntut agar pemerintah melakukan penegakan hukum yang diwajibkan kepadanya atau untuk memulihkan kerugian publik atas pelanggaran yang terjadi.

${ }^{11}$ E. Sundari, 2000, Pengajuan Gugatan Secara Class Action (Suatu Studi Perbandingan dan Penerapannya di Indonesia), Yogyakarta: Universitas Atma Jaya Yogyakarta, h.18.

12 Steven C. Hackett. 2011. Environmental and Natural Resources Economic: Theory, Policy, and the Sustainable Society. Fourth edition, London\&New York: Routlege Taylor and Fracis Group. h.217

13 Abdul Fatah, Gugatan Warga Negara Sebagai Mekanisme Pemenuhan Hak Asasi Manusia dan Hak Konstitusional Warga Negara, Jurnal Yuridika, Volume 28 No. 3, September-Desember 2013, h.296.

14 MC.Mehta v.Union of India, AIR 1988 SC 1037 Gangga Pollution (Tanneries) Case. Lihat juga MC.Mehta v.Union of India, AIR 1988 SC 11 15.Gangga Pollution (Municipalities) Case. Seorang warga negara India bernama Mehta menggugat otoritas pemerintah India karena dianggap melakukan kelalaian dalam melakukan langkah-langkah efektif untuk mencegah pencemaran lingkungan yang terjadi di Sungai Gangga. Mehta memohon kepada pengadilan agar memutus pemerintah India untuk memerintahkan agar industri penyamakan kulit dan korporasi menghentikan pembuangan limbahnya ke Sungai Gangga. Pengadilan lalu membagi permohonan Mehta ini menjadi 2 bagian yaitu MC.Mehta v.Union of India, AIR 1988 SC 1037 terkait pencemaran Sungai Gangga yang disebabkan karena pembuangan limbah yang berasal dari industri penyamakan kulit dan MC.Mehta v.Union of India, AIR 1988 SC 1115 terkait pencemaran Sungai Gangga yang disebabkan karena pembuangan limbah yang berasal municipal corporation.

${ }^{15}$ Dalam kasus ini Pengadilan mengadopsi prinsip-prinsip dalam hukum internasional seperti precautionary principle, polluter pays principle dan the concept of sustainable development as part of law of the land. Kasus ini juga sekaligus menunjukkan bahwa doktrin atas hak riparian (riparian rights) diakui.Riparian adalah seseorang yang memiliki rumah atau tanah yang bersebelahan dengan sungai atau sumber air. Seorang riparian berhak untuk menggunakan air sungai yang melewati tanahnya dan berhak untuk mendapatkan manfaat dari sumber air yang bebas dari pencemaran. Ruchi Pant. 2003. From Communities Hands to MNCs BOOTs: A Case Study From India on Right to Water, Submitted to Rights and Humanity, UK, h.12, http://www.ircwash.org/sites/ default/files/Pant-2003-Communities.pdf. 


\section{KERTHA PATRIKA}

Volume 38, Nomor 1, Januari-April 2016

Pada intinya citizen law suit merupakan mekanisme bagi Warga Negara untuk menggugat tanggung jawab penyelenggara Negara dalam hal ini pemerintah atas kelalaian dalam memenuhi hak-hak warga negara. Kelalaian tersebut dapat didalilkan sebagai Perbuatan Melawan Hukum, ${ }^{16}$ sehingga citizen law suitdiajukan pada lingkup perkara perdata yang masuk dalam ranah peradilan umum. Bila terbukti lalai, Negara dihukum untuk mengeluarkan suatu kebijakan yang bersifat mengatur umum (regeling) agar kelalaian tersebut tidak terjadi lagi di kemudian hari.

Dalam Laporan Penelitian Class Action dan Citizen Lawsuit yang dibuat oleh Mahkamah Agung tahun 2009, isi petitum yang dapat diajukan dalam citizen law suit antara lain, adalah: ${ }^{17}$

1. Petitum dalam gugatan tidak boleh meminta adanya ganti rugi materiil, karena warga negara yang menggugat bukan kelompok yang dirugikan secara materiil dan memiliki kesamaan kerugian dan kesamaan fakta hukum sebagaimana class action.

2. petitum citizen law suit harus berisi permohonan agar negara mengeluarkan suatu kebijakan pengaturan umum agar perbuatan melawan hukum berupa kelalaian dalam pemenuhan hak warga negara tersebut di masa mendatang tidak terjadi lagi.

3. Petitum citizen law suit tidak boleh berupa pembatalan atas keputusan penyelenggara negara (Keputusan Tata Usaha Negara) yang bersifat kongkrit, individual, dan final karena hal tersebut merupakan kewenangan dari Pengadilan Tata Usaha Negara (PTUN).

4. Petitum citizen law suit juga tidak boleh berupa pembatalan atas suatu undang-undang (UU) karena itu merupakan kewenangan dari Mahkamah Konstitusi (MK). Selain itu, citizen law suit juga tidak boleh meminta pembatalan atas peraturan perundang-undangan di bawah Undang-Undang karena hal tersebut merupakan kewenangan Mahkamah Agung (MA) berdasarkan judicial review.

Seperti halnya dengan prosedur citizen law suit di beberapa negara, maka dalam praktiknya di Indonesia, disyaratkan adanya notifikasi terlebih dahulu dari penggugat kepada tergugat. Notifikasi merupakan proses khusus semacam somasi, dalam bentuk pernyataan (statement) dari penggugat kepada tergugat yang sudah berisi dasar pelanggaran dan tuntutan spesifik yang dimintakan. Notifikasi ini harus dilakukan terlebih dahulu sebelum gugatan memasuki tahap administratif diajukan ke pengadilan. Suatu notifikasi di dalam citizen law suit di Indonesia sekurangkurangnya memuat ${ }^{18}$ :

1. Informasi tentang pelanggar yang dituduh dan lembaga yang relevan dengan pelanggaran,

\footnotetext{
${ }^{16}$ Perbuatan Melawan Hukum (PMH) diatur dalam pasal 1365 KUHPerdata. Pasal ini sering disebut pasal all catches atau pasal "keranjang sampah". Pasal 1365 KUHPerdata merupakan ketentuan umum tentang perbuatan melawan hukum, tidak membedakan anatara suatu perbuatan melawan hukum yang dilakukan oleh pemerintah, badan hukum, atau perseorangan, sehingga pasal ini merupakan ketentuan yang bersifat sangat terbuka.Dengan demikian, tidak mengherankan jika telah terjadi perkembangan dalam penerapan Pasal 1365 KUHPerdata. Lihat Rosa Agustina, 2003, Perbuatan Melawan Hukum, Jakarta: Program Pasca Sarjana Fakultas Hukum Universitas Indonesia, h. 3

${ }^{17}$ Mahkamah Agung, 2009, Laporan Penelitian Class action dan Citizen Lawsuit, Bogor: Badan Penelitian, Pengembangan, Pendidikan dan Pelatihan Hukum dan Mahkamah Agung RI, h. 65.

18 Ibid.
}

36 | Jurnal Ilmiah Fakultas Hukum Universitas Udayana 
yang berdasar hal tersebut penggugat atau para penggugat berniat menggugat tergugat/para tergugat.

2. Jenis pelanggaran yang menimbulkan obyek gugatan.

Terkait dengan notifikasi ini dalam praktek di Indonesia, terdapat gugatan warga negara (citizen law suit) yang ditolak oleh Majelis Hakim karena tidak didahului dengan adanya notifikasi dari penggugat kepada tergugat. Contohnya yaitu dalam kasus gugatan warga negara (citizen law suit) warga terhadap kenaikan harga bahan bakar minyak (BBM) yang diajukan ke Pengadilan Negeri Jakarta Pusat pada tahun 2014. Majelis Hakim memutuskan bahwa gugatan penggugat tidak dapat diterima dengan dasar bahwa penggugat tidak memenuhi syarat formil dari model citizen law suit. ${ }^{19}$

Syarat formil yang tak dipenuhi penggugat adalah mengenai pengiriman notifikasi penggugat kepada para tergugat. Oleh karena hukum Indonesia belum mengatur secara jelas praktik citizen law suit, Majelis hakim harus merujuk praktik citizen law suit di negara-negara yang menggunakan mekanisme gugatan citizen law suit. Pada negara-negara yang menganut sistem Common Law sebagai pengguna model citizen law suit, biasanya mengharuskan penggugat mengirim notifikasi terlebih dahulu selambat-lambatnya dua bulan sebelum gugatan warga negara diajukan. Tujuannya adalah untuk memberikan kesempatan kepada penyelenggara negara memperhatikan atau memperbaiki objek yang akan digugat. Selain itu, notifikasi bisa juga bertujuan untuk memberitahukan ada warga negara yang ingin menggugat penyelenggara negara tersebut. ${ }^{20}$

Untuk mempermudah klasifikasi pembedaan antara karakteristik citizen law suit, dengan gugatan-gugatan lainnya, maka dapat dilihat melalui tabel berikut:

\section{Tabel 1}

Perbedaan karakteristik Gugatan Perdata biasa, Class Action, Judicial Review, Legal Standing dan Citizen Lawsuit ${ }^{21}$

\begin{tabular}{|c|l|l|l|l|l|}
\hline $\begin{array}{c}\text { Karakteris- } \\
\text { tik }\end{array}$ & $\begin{array}{c}\text { Gugatan } \\
\text { Perdata Biasa }\end{array}$ & Class Action & \multicolumn{1}{c|}{$\begin{array}{c}\text { Judicial } \\
\text { Review }\end{array}$} & \multicolumn{1}{c|}{$\begin{array}{c}\text { Legal } \\
\text { standing }\end{array}$} & \multicolumn{1}{c|}{$\begin{array}{c}\text { Citizen } \\
\text { Lawsuit }\end{array}$} \\
\hline Terminologi & $\begin{array}{l}\text { Gugatan Per- } \\
\text { buatan Melawan } \\
\text { Hukum }\end{array}$ & $\begin{array}{l}\text { Gugatan } \\
\text { Perwakilan } \\
\text { Kelompok }\end{array}$ & $\begin{array}{l}\text { Uji Materiil } \\
\text { UU terhadap } \\
\text { Konstitusi }\end{array}$ & $\begin{array}{l}\text { Gugatan Non } \\
\text { Governmental } \\
\text { Organization }\end{array}$ & $\begin{array}{l}\text { Gugatan warga } \\
\text { negara }\end{array}$ \\
\hline
\end{tabular}

${ }^{19}$ Lihat “Gugatan CLS Kenaikan Harga BBM Kandas Karena Notifikasi”'http://www.hukumonline.com/berita/baca/ 1t52fd0499e4ec3/gugatan-cls-kenaikan-harga-bbm-kandas-karena-notifikasi.Lihat juga "Melalui Citizen Lawsuit, Masyarakat Bisa Gugat Pemerintah" http://www.hukumonline.com/berita/baca/hol19251/melalui-citizen-lawsuit-masyarakat-bisa-gugat-pemerintah.

${ }^{20}$ Penggugat berdalih bahwa konferensi pers, artikel-artikel di media massa, dan brosur seputar gugatan kenaikan BBM bersubsidi ini seharusnya bisa dianggap sebagai bentuk peringatan (notifikasi) kepada penyelenggara negara. Majelis Hakim ternyata tidak sepakat dengan dalil tersebut karena berpandangan bahwa artikel-artikel di media massa tidak masuk kategori notifikasi. Masalahnya, artikel-artikel dan brosur tidak memenuhi syarat-syarat dari pemateraian, yaitu dikirimkan kepada pihak yang dituju dan dibuktikan dengan tanda terima. Dengan demikian konferensi pers dan brosur tidak dapat dihubungkan dengan mekanisme notifikasi. Lihat http://www.hukumonline.com/berita/baca/lt52fd0499e4ec3/gugatan-cls-kenaikan-harga-bbm-kandaskarena-notifikasi, diakses tanggal 14 Februari 2014.

${ }^{21}$ Diolah oleh penulis dari berbagai sumber. 
KERTHA PATRIKA

Volume 38, Nomor 1, Januari-April 2016

\begin{tabular}{|c|c|c|c|c|c|}
\hline Filosofis & $\begin{array}{l}\text { Memperjuang- } \\
\text { kan kepentingan } \\
\text { individu }\end{array}$ & $\begin{array}{l}\text { Ketidakper- } \\
\text { cayaan pada } \\
\text { individualistik- } \\
\text { dan menyeder- } \\
\text { hanakan meka- } \\
\text { nisme gugatan } \\
\text { dengan per- } \\
\text { wakilan }\end{array}$ & $\begin{array}{l}\text { Melindungi } \\
\text { hak konstitu- } \\
\text { sional warga } \\
\text { negara }\end{array}$ & $\begin{array}{l}\mathrm{NGO/} \\
\text { LSM sebagai } \\
\text { wali (guard- } \\
\text { ian) }\end{array}$ & $\begin{array}{l}\text { Individu mem- } \\
\text { perjuangkan } \\
\text { kepentingan } \\
\text { publik, agar } \\
\text { penyeleng- } \\
\text { gara negara } \\
\text { memperbaiki } \\
\text { kebijakan yang } \\
\text { dinilai mer- } \\
\text { ugikan kepent- } \\
\text { inganpublik/ } \\
\text { warga negara }\end{array}$ \\
\hline $\begin{array}{l}\text { Hubungan } \\
\text { Kepentingan }\end{array}$ & $\begin{array}{l}\text { Kepentingan } \\
\text { langsung, nyata } \\
\text { dan bisa diukur } \\
\text { (riil dan tan- } \\
\text { gible) }\end{array}$ & $\begin{array}{l}\text { Kepentingan } \\
\text { langsung, } \\
\text { nyata dan bisa } \\
\text { diukur } \\
\text { (riil dan tan- } \\
\text { gible) }\end{array}$ & $\begin{array}{l}\text { Kepentingan } \\
\text { langsung dan } \\
\text { tidak lang- } \\
\text { sung }\end{array}$ & $\begin{array}{l}\text { Tidak memi- } \\
\text { liki kepentin- } \\
\text { gan langsung }\end{array}$ & $\begin{array}{l}\text { Tidak memiliki } \\
\text { kepentingan } \\
\text { yang riil dan } \\
\text { terukur }\end{array}$ \\
\hline Tuntutan & $\begin{array}{l}\text { Ganti Rugi ma- } \\
\text { teriil \&tindakan } \\
\text { tertentu }\end{array}$ & $\begin{array}{l}\text { Ganti Rugi } \\
\text { materiil \&tin- } \\
\text { dakan tertentu }\end{array}$ & $\begin{array}{l}\text { Pembatalan } \\
\text { ketentuan } \\
\text { pasal dalam } \\
\text { UU baik se- } \\
\text { luruh maupun } \\
\text { sebagian }\end{array}$ & $\begin{array}{l}\text { Tindakan } \\
\text { tertentu dan } \\
\text { out of pocket } \\
\text { expenses }\end{array}$ & $\begin{array}{l}\text { Tindakan } \\
\text { tertentu berupa } \\
\text { pelaksanaan } \\
\text { kewajiban } \\
\text { kuhum oleh } \\
\text { penyeleng- } \\
\text { gara negara } \\
\text { (regeling) }\end{array}$ \\
\hline $\begin{array}{l}\text { Subjek Peng- } \\
\text { gugat }\end{array}$ & $\begin{array}{l}\text { Orang yang } \\
\text { dirugikan secara } \\
\text { langsung }\end{array}$ & $\begin{array}{l}\text { Class Member- } \\
\text { dan Class Rep- } \\
\text { resentative }\end{array}$ & $\begin{array}{l}\text { Warga negara } \\
\text { atau NGO } \\
\text { yang memi- } \\
\text { liki legal } \\
\text { standing }\end{array}$ & $\begin{array}{l}\text { Organisasi } \\
\text { yang me- } \\
\text { menuhi } \\
\text { persyaratan }\end{array}$ & $\begin{array}{l}\text { Warga negara } \\
\text { atau NGO } \\
\text { yang memiliki } \\
\text { legal standing }\end{array}$ \\
\hline $\begin{array}{l}\text { Ter } \\
\text { gugat }\end{array}$ & $\begin{array}{l}\text { Orang- peroran- } \\
\text { gan atau badan } \\
\text { hukum }\end{array}$ & $\begin{array}{l}\text { Orang-per- } \\
\text { orangan atau } \\
\text { badan hukum }\end{array}$ & $\begin{array}{l}\text { Pembentuk } \\
\text { UU (DPR dan } \\
\text { Presiden) }\end{array}$ & \begin{tabular}{|l} 
Orang-per- \\
orangan atau \\
badan hukum, \\
penyeleng- \\
gara negara
\end{tabular} & $\begin{array}{l}\text { Penyelenggara } \\
\text { Negara (Presi- } \\
\text { den, Kemente- } \\
\text { rian, BUMN) }\end{array}$ \\
\hline Notifikasi & $\begin{array}{l}\text { Tidak diperlukan } \\
\text { Notifikasi }\end{array}$ & $\begin{array}{l}\text { Notifikasi dari } \\
\text { Class Repre- } \\
\text { sentativeke } \\
\text { Class Member }\end{array}$ & $\begin{array}{l}\text { Notifikasi } \\
\text { dari Pemo- } \\
\text { hon kepada } \\
\text { Termohon }\end{array}$ & $\begin{array}{l}\text { Tidak diperlu- } \\
\text { kan Notifikasi }\end{array}$ & $\begin{array}{l}\text { Notifikasi dari } \\
\text { Penggugat ke- } \\
\text { pada Tergugat }\end{array}$ \\
\hline
\end{tabular}

Prosedur pengajuan permohonan citizen law suit secara khusus belumlah diatur dalam peraturan perundang-undangan di Indonesia. Pengaturan yang telah ada yaitu mengenai gugatan class action dan legal standing. Pertama kalinya, prosedur permohonan citizen law suit diterima oleh Pengadilan Negeri Jakarta Pusat dan telah memiliki kekuatan hukum tetap dalam perkara perdata Nomor: 28/Pdt.G/2003/PN.JKT.PST, yang diputus pada tanggal 8 Desember 2003. ${ }^{22}$

22 Perkara ini berkaitan dengan pendeportasian 480 ribu warga negara Republik Indonesia oleh Pemerintah Malaysia yang menjadi buruh migran di Malaysia. Penelitian kalangan LSM menunjukkan bahwa para buruh sudah diperlakukan tidak manusiawi sejak masa pengiriman hingga terusir dari Malaysia dan menunjukkan parahnya perlindungan hukum (dari Pemerintah) 
Majelis hakim dalam perkara ini melakukan terobosan hukum. Saat mengeluarkan penetapan atas pemeriksaan pendahuluan, Majelis hakim menyetujui mekanisme citizen law suit, walaupun dasar hukumnya masih menimbulkan pro dan kontra. Dalam putusan tersebut, Majelis hakim berargumen bahwa berdasarkan Undang-Undang Nomor 14 Tahun 1970 tentang Kekuasaan Kehakiman, ${ }^{23}$ hakim tidak boleh menolak untuk menangani perkara. Hakim berkewajiban untuk menggali hukum yang hidup di dalam masyarakat. Hakim tidak boleh menolak perkara walau belum ada dasar hukumnya. Uraian majelis hakim memang sejalan dengan Pasal 14 ayat (1) UU No. 14 Tahun 1970 yang mengatur bahwa Pengadilan tidak boleh menolak untuk memeriksa dan mengadili sesuatu perkara yang diajukan dengan dalih bahwa hukum tidak atau kurang jelas, melainkan wajib untuk memeriksa dan mengadilinya. ${ }^{24}$

Secara filosofis, setiap warga negara berhak untuk membela kepentingan umum atau kepentingan publik. ${ }^{25}$ Selain itu, tuntutan hukum masyarakat dewasa ini semakin menempatkan pengadilan sebagai tumpuan harapan untuk mencari keadilan dan terobosan-terobosan hukum. Gugatan model citizen law suit menggugat otoritas negara (pemerintah) untuk sesuatu tindakan yang merugikan kepentingan umum ataupun menuntut pemerintah agar melakukan tindakan secara aktif untuk kepentingan umum.

Terkait dengan pemenuhan HAM warga negara, Pasal 28 I ayat (4) UUD NRI Tahun 1945 dan Pasal 71 UU HAM dengan tegas menyatakan bahwa perlindungan, pemajuan, penegakan dan pemenuhan HAM adalah tanggung jawab negara, terutama Pemerintah. Di samping itu, Pasal 7 ayat (1) UU HAM memberikan hak kepada setiap orang untuk melakukan semua upaya hukum atas terjadinya pelanggaran HAM.

Mochtar Kusumaatmaja menyatakan bahwa hukum yang memadai tidak hanya memandang hukum itu sebagai suatu perangkat kaídah dan asas-asas yang mengatur kehidupan manusia dalam masyarakat, tetapi juga mencakup lembaga (institution) dan proses yang diperlukan untuk mewujudkan hukum itu dalam kenyataan. ${ }^{26}$ Dengan demikian, walaupun belum ada pengaturan, landasan hukumnya atau pelembagaannya gugatan warga negara atau citizen law suit dapat

terhadap buruh migran.Pemerintah terkesan tidak tanggap. Gugatan terhadap tragedi yang menewaskan 79 orang buruh migran itu dikenal sebagai perkara dengan sebutan citizen law suit Nunukan. Para pihak yaitu J. Sandyawan Sumardi dan kawan-kawan (sebanyak 53 orang) sebagai Pemohon melawan Negara Republik Indonesia c.q. Kepala Negara, Presiden Republik Indonesia Megawati Soekarnoputri sebagai Tergugat (termasuk sembilan institusi pemerintah lainnya). Perkara ini bisa menjadi rujukan baik bagi gugatan-gugatan sejenis di masa mendatang. Perjalanan sidang atas perkara ini begitu berliku. Beberapa kali sidang ditunda karena tergugat -- antara lain presiden dan lima menteri -- maupun kuasa hukumnya tidak hadir. Penyebabnya, tidak lain adalah surat kuasa. Masalah surat kuasa tergugat sampai memakan waktu hingga tiga kali persidangan. Hal lain yang dipersoalkan adalah keputusan hakim untuk melakukan pemeriksaan pendahuluan terhadap gugatan para penggugat. Masalahnya adalah pemeriksaan pendahuluan (dismissal process) hanya dikenal dalam gugatan Tata Usaha Negara (TUN), tidak dalam gugatan perdata.

23 Telah diubah melalui Undang-Undang Nomor48 Tahun 2009 tentang Kekuasaan Kehakiman.

24 Lihat lebih lanjut dalam "Pro Kontra Citizen law Suit: Belajar Dari Kasus Nunukan". http://www.hukumonline.com/ berita/baca/hol8003/prokontra-citizen-law-suit-belajar-dari-kasus-nunukan

25 Salah satu asas dasar utama yang penting dalam hukum acara perdata adalah asas point d'interet point d'action yang berarti bahwa barangsiapa mempunyai kepentingan dapat mengajukan tuntutan hak atau gugatan. Kepentingan di sini lebih mengacu pada kepentingan hukum secara langsung, yaitu kepentingan yang dilandasi dengan adanya hubungan hukum antara penggugat dan tergugat dan hubungan hukum itu langsung dialami sendiri secara konkrit oleh penggugat. Sudikno Mertokusumo, 2006, Hukum Acara Perdata Indonesia, Jakarta: Penerbit Liberty, h 53. Manusia selain sebagai makhluk individu juga merupakan makhluk sosial. Oleh karena itu dalam kehidupan bermasyarakat, kepentingan individu tidak terlepas dari kepentingan masyarakat di sekitarnya.

26 Mochtar Kusumaatmadja. 1976. Hukum, Masyarakat dan Pembinaan Hukum Nasional, Bandung: Binacipta, h.3. 


\section{KERTHA PATRIKA}

Volume 38, Nomor 1, Januari-April 2016

diterima untuk diajukan ke mekanisme pengadilan, lebih khususnya dalam hal tuntutan untuk pemenuhan HAM yang dimiliki oleh masing-masing warga negara. Hal ini semata-mata juga sebagai sarana alternatif yang dapat dipergunakan sebagai wujud perlindungan hukum kepada warga negara dari terjadinya tindakan pembiaran yang dilakukan oleh otoritas negara.

\section{Isu Justiciability ${ }^{27}$ Hak Ekonomi, Sosial dan Budaya (Hak Ekosob)}

Hak Asasi Manusia (HAM) merupakan hak yang melekat pada manusia karena hakekat dan kodratnya sebagai manusia. HAM bersifat inheren atau melekat pada diri manusia itu sendiri, bukan karena pemberian oleh seseorang atau oleh suatu organisasi kekuasaan manapun termasuk negara. Untuk itu, pada dasarnya hak-hak tersebut tidak boleh dirampas atau dicabut. Senada dengan yang ditulis oleh Jack Donnelly bahwa "human rights are that human beings posses because they are human beings. ${ }^{28}$

Ahli hukum Perancis, Karel Vasak mengemukakan perkembangan pemikiran HAM dengan mengklasifikasikannya menjaadi tiga generasi yang terinspirasi oleh tiga tema Revolusi Perancis, yaitu HAM Generasi Pertama (Hak Sipil dan Politik/Liberte); HAM Generasi Kedua (Hak Ekonomi, Sosial dan Budaya/Egalite) dan HAM Generasi Ketiga, Hak Solidaritas (Fraternite). Tiga generasi ini perlu dipahami sebagai satu kesatuan, saling berkaitan dan saling melengkapi. Karel Vasak menggunakan istilah "generasi” untuk menunjuk pada substansi dan ruang lingkup hak-hak yang diprioritaskan pada satu kurun waktu tertentu. ${ }^{29}$

Ketiga generasi HAM tersebut dapat diuraikan sebagai berikut: ${ }^{30}$

1. HAM generasi pertama mencakup prinsip integritas manusia, kebutuhan dasar manusia, dan prinsip kebebasan sipil dan politik, yang lebih dikenal dengan hak sipil dan politik. Termasuk dalam generasi pertama ini adalah hak hidup, hak kebebasan bergerak, perlindungan terhadap hak milik, kebebasan berpikir, beragama dan berkeyakinan, kebebasan berkumpul dan menyatakan pikiran, hak bebas dari penahanan dan penangkapan sewenang-wenang, hak bebas dari hukum yang berlaku surut, dan sebagainya. Hak-hak generasi pertama ini sering pula disebut sebagai "hak-hak negatif" karena negara tidak boleh berperan aktif (positif) terhadapnya, karena akan mengakibatkan pelanggaran terhadap hak-hak dan kebebasan tersebut. Hak sipil dan politik ini telah diadopsi dalam suatu kovenan yaitu 'International Covenant on Civil and Political Rights'(ICCPR).

2. Pada perkembangan selanjutnya dikemukakan apa yang disebut HAM Generasi Kedua. Konsepsi HAM generasi ini mencakup upaya menjamin pemenuhan kebutuhan untuk mengejar kemajuan ekonomi, sosial dan kebudayaan, termasuk hak atas pendidikan, hak untuk me-

27 Lihat catatan kaki nomor 5.

28 Lihat Jan Berting, et.al., 1990. Human Rights in a Pluralist World: Individuals and Collectivities. First Edition, London: Meckler. h.33. Lihat juga bagaimana konsep hak asasi manusia dalam sistem ketatanegaraan Indonesia dalam Jimly Asshiddiqie, 2012, Hukum Tata Negara dan Pilar-Pilar Demokrasi, Jakarta: Penerbit Sinar Grafika, h.198-234.

29 Lihat Karel Vasak. 1982. the International Dimensions of Human Rights, Volume 1. Connecticut: Greenwood Press and France: UNESCO.

30 Ibid. 
nentukan status politik, hak untuk menikmati ragam penemuan penemuan-penemuan ilmiah, dan lain-lain sebagainya. Puncak perkembangan kedua ini tercapai dengan ditandatanganinya 'International Covenant on Economic, Social and Cultural Rights' (ICESCR) pada tahun 1966. Termasuk dalam generasi kedua ini adalah hak atas pekerjaan dan upah yang layak, hak atas jaminan sosial, hak atas pendidikan, hak atas kesehatan, hak atas pangan, hak atas perumahan, hak atas tanah, hak atas lingkungan hidup yang baik dan sehat, dan sebagainya. Dalam pemenuhan hak-hak generasi kedua ini negara dituntut bertindak lebih aktif (positif), sehingga hak-hak generasi kedua ini disebut juga sebagai "hak-hak positif". Pemenuhan hak-hak ini membutuhkan peran aktif dari negara.

3. Hak-hak generasi ketiga diwakili oleh tuntutan atas "hak solidaritas"” atau "hak bersama". Hak-hak ini muncul dari tuntutan dari negara-negara berkembang atau Dunia Ketiga atas tatanan internasional yang adil. Melalui tuntutan atas hak solidaritas itu, negara-negara berkembang menginginkan terciptanya suatu tatanan ekonomi dan hukum internasional yang kondusif bagi terjaminnya hak-hak berikut: (i) hak atas pembangunan; (ii) hak atas perdamaian; (iii) hak atas sumber daya alam sendiri; (iv) hak atas lingkungan hidup yang baik dan (v) dan hak atas warisan budaya sendiri.

Pembagian masing-masing generasi HAM tersebut didasari oleh pembedaan pemikiran filofofis yang melatarbelakangi masing-masing hak tersebut. Pieter van Dijk mengkritik pembagian HAM ke dalam generasi tertentu karena seakan-akan mengandaikan bahwa generasi yang satu muncul terlebih dahulu dibandingkan dengan generasi lainnya. ${ }^{31}$ Pandangan skeptis menyatakan bahwa hak ekosob merupakan 'positive rights' sedangkan hak sipil politik merupakan 'negative rights'. Pengertian 'negatif' dan 'positif' ini merujuk pada perlu tidaknya campur tangan negara yang pada akhirnya berpengaruh terhadap ada tidaknya biaya yang diperlukan berhubungan dengan realisasi hak-hak bersangkutan. ${ }^{32}$ Dengan kata lain hak sipil dan politik dianggap tidak memerlukan campur tangan negara, sedangkan implementasi hak ekonomi dan sosial memerlukan intervensi aktif dari negara.

Pembedaan secara 'positif' dan 'negatif' demikian tidaklah sepenuhnya benar. Membedakan HAM dalam dua kelompok seperti ini merupakan penyesatan, karena perlindungan dan pemajuan hak-hak sipil politik juga membutuhkan keterlibatan negara dan sebaliknya dengan hak ekosob. Sebagai contoh, hak atas rasa aman dan hak atas proses peradilan yang benar mensyaratkan keterlibatan atau tindakan afirmatif negara seperti pembentukan sistem hukum pidana, penyediaan ruang tahanan dan aparat hukum (kantor kepolisian, kejaksaan, ruang pengadilan) serta pendidikan pada para pejabat keamanan bersangkutan. Sulit dibayangkan adanya larangan penyiksaan dalam hukum pidana materiil tanpa penahanan, pengadilan maupun penghukuman bagi pelaku. Penciptaan ruang-ruang pengadilan atau ruang tahanan (yang manusiawi) itu tentu memakan biaya yang sangat besar. ${ }^{33}$

31 Lihat Pieter van Dijk dalam Hukum Internasional tentang Hak Asasi Manusia dalam Adnan Buyung Nasution,et.al, Instrumen International Pokok Hak-hak Asasi Manusia, Edisi ke 2, Jakarta: Yayasan Obor Indonesia, h. 3-57.

32 Baca Ifdhal Kasim, 2007, Seri Bahan Bacaan Kursus HAM Untuk Pengacara XI Tahun 2007, Materi: Kovenan HakHak Sipil dan Politik, Jakarta: Lembaga Studi dan Advokasi Masyarakat (ELSAM), h.2.

33 Antonio Prasojo, "Membela Hak Asasi Ekonomi dan Sosial”, Jurnal HAM, Volume 1 No.1, 1 Oktober 2003, h. 6. 


\section{KERTHA PATRIKA}

Volume 38, Nomor 1, Januari-April 2016

Menurut Cees Flinterman generasi pertama yang terdiri dari hak sipil dan politik atau biasa disebut dengan hak klasik, didasarkan pada konsep awal dari HAM yaitu melindungi individu dari tindakan sewenang-wenang negara, sehingga HAM generasi pertama ini menjamin pada kebebasan individu untuk melaksanakan kebebasan pribadi (personal freedom) sebagai realisasi HAM individu. Sedangkan untuk HAM generasi kedua yaitu hak ekonomi, sosial dan budaya lebih kepada memberikan kewajiban penguasa (authority) untuk menciptakan suatu kondisi dimana HAM dapat berkembang, misalnya pendidikan (education), pekerjaan (employment), kesehatan (health care), dan jaminan sosial (social security) hak demikian ini merupakan realisasi dari hak asasi manusia kolektif. ${ }^{34}$

Perbedaan antara HAM generasi pertama dan HAM generasi kedua bukan hanya sekedar kewajiban yang bersifat negatif (generasi pertama) dan kewajiban yang bersifat positif (generasi kedua). ${ }^{35}$ Tetapi juga kewajiban yang dapat langsung dilaksanakan oleh negara (generasi pertama) dan kewajiban yang tidak dapat langsung dilaksanakan karena membutuhkan waktu serta perencanaan melalui kebijakan publik (generasi kedua).

Turunan dari keraguan-keraguan di atas adalah anggapan bahwa hak ekosob tidak memiliki kemungkinan untuk diajukan ke pengadilan jika hak ini dilanggar (non justiciable) karena penerapan hak ekonomi dan sosial adalah persoalan politik. ${ }^{36}$ Hak-hak atas kerja, kesehatan, makan, pakaian, perumahan dan pendidikan dianggap sebagai program-program kebijakan negara di bidang bersangkutan dan bukan HAM. Argumen ini diperkuat dengan tiadanya mekanisme internasional untuk menuntut keadilan atas pelanggaran hak ekosob.

Sifat kewajiban yang berbeda dari negara-negara pihak dalam ICCPR dan ICESCR juga memunculkan tanya, apakah memangkonstruksi hak ekosob tidak memiliki justiciability.

\section{Menurut Article 2(1) ICCPR:}

"Each State Party to the present Covenant undertakes to respect and to ensure to all individuals within its territory and subject to its jurisdiction the rights recognized in the present Covenant, without distinction of any kind, such as race, colour, sex, language, religion, political or other opinion, national or social origin, property, birth or other status."

Ketentuan ini menggariskan bahwa setiap negara pihak ICCPR berusaha untuk menghormati dan menjamin hak-hak yang diakui dalam kovenan ini terhadap semua individu dalam wilayah kekuasaannya.

Pendekatan ICESCR sangat berbeda dengan ICCPR. Dalam Article 2(1) ICESCR diatur bahwa:

"Each State Party to the present Covenant undertakes to take steps, individually and through international assistance and co-operation, especially economic and technical, to the maximum of its available resources, with a view to achieving progressively the full realization of the rights recognized in the present Covenant by all appropriate means, including particularly the adoption of legislative measures."

\footnotetext{
34 Jan Berting, Op.cit, h.76.
}

35 Ibid.

36 Persoalan politik di sini yaitu bahwa penerapan hak ekonomi, sosial dan budaya tergantung dari arah kebijakan ataupun political will pemerintahan negara yang bersangkutan. 
Ketentuan di atas memperlihatkan pendekatan ICESCR yang memperhatikan kemampuan sumber daya masing-masing negara yang menentukan negara-negara untuk mengambil langkah-langkah secara maksimum dengan segala sumber daya yang ada, untuk secara progresif mencapai perwujudan penuh dari hak-hak yang diakui dalam kovenan ini dengan cara-cara yang tepat.

Dengan demikian, kewajiban negara-negara pihak dalam ICESCR tidak dalam arti pemenuhan yang bersifat segera, tetapi secara bertahap yaitu dengan cara mengambil atau menyusun langkah-langkah tertentu untuk mencapai perwujudan hak ekosob secara penuh. Dalam hal ini, pemenuhan atas hak-hak tersebut juga dapat disesuaikan dengan kemampuan masingmasing negara.

Selain itu, terdapat perbedaan lain terkait dengan cara bagaimana hak-hak substantif dirumuskan melalui susunan kata-kata. ICCPR cenderung menggunakan rumusan klasik "Setiap orang mempunyai hak untuk...." atau "Tidak seorangpun yang bisa diperlakukan... “. Sedangkan rumusan ICESCR lebih sering menggunakan rumusan aturan yang kurang tegas, misalnya, "Negara-negara pihak kovenan ini mengakui hak...".

Dalam perkembangan hukum HAM internasional saat ini, hak ekosob tidak lagi dapat dikatakan sebagai "hak kelas dua". Dalam perkembangannya hak ekosob dapat diajukan ke muka lembaga peradilan dan korban pelanggarannya dapat memperoleh kompensasi hukum.

Dalam ranah hukum domestik, hal ini dapat dilakukan dengan mengimplementasikan prinsipprinsip universalitas hak-hak itu kedalam sistem hukum nasional. Sumber yang paling eksplisit dan utama dari hak ekosob adalah Deklarasi Umum Hak Asasi Manusia (DUHAM) yang diadopsi pada tahun 1948 yang kemudian dielaborasi dan dijabarkan lebih lanjut dalam ICESCR disahkan pada tahun 1966 dan telah diratifikasi oleh 164 negara. ${ }^{37}$ Bersama dengan ICCPR, instrumeninstrumen tersebut menjadi acuan utama instrumen-instrumen HAM lainnya. ${ }^{38}$

\section{Hak Gugat Warga Terhadap Jaminan Pemenuhan Hak Atas Lingkungan Hidup Yang Baik dan Sehat}

Lingkungan hidup adalah kesatuan ruang dengan semua benda, daya, keadaan dan mahkluk hidup, termasuk manusia dan perilakunya yang mempengaruhi alam itu sendiri, kelangsungan perikehidupan, dan kesejahteraan manusia serta mahkluk hidup lain. ${ }^{39}$ Lingkungan hidup di alam bumi merupakan bagian yang terpenting bagi kehidupan umat manusia. Akan tetapi dalam perkembangannya sekarang ini, lingkungan hidup telah banyak mengalami kerusakan-kerusakan. Kerusakan tersebut dapat disebabkan karena proses alam maupun juga dapat disebabkan akibat ulah manusia yang kurang memahami peran lingkungan dan alam sekitarnya. Berbagai kegiatan dan kebijakan yang dilakukan manusia, seperti kegiatan perindustrian, kegiatan pertambangan, pembangunan infrastruktur daerah, pengalihan status kawasan hutan dan lahan, secara

\footnotetext{
37 Lihat https://treaties.un.org/Pages/ViewDetails.aspx?src=TREATY\&mtdsg_no=IV-3\&chapter=4\&lang=en.

38 Antonio Prasojo, Op.Cit.

39 Pasal 1 ayat (1) Undang-Undang Nomor 32 Tahun 2009 tentang Pengelolaan dan Perlindungan Lingkungan Hidup.
} 


\section{KERTHA PATRIKA}

Volume 38, Nomor 1, Januari-April 2016

nyata banyak yang dilakukan tanpa mengindahkan perlindungan terhadap kehidupan lingkungan alam. Akibatnya kerusakan dan pencemaran lingkungan hidup merajalela. ${ }^{40}$

Ben Boer memaparkan bahwa warga negara mempunyai hak untuk mengakses informasi, hak untuk berpartisipasi dalam kebijakan lingkungan yang mempengaruhinya (atau berdampak baginya), hak akses untuk menuntut keadilan ke pengadilan dan mekanisme lainnya. ${ }^{41}$

Penegakan justiciability ${ }^{42}$ hak atas lingkungan hidup yang baik dan sehat juga menjadi bagian dari pemenuhan hak ekosob. Secara teoritis, justiciability hak atas lingkungan hidup yang baik dan sehat tidak perlu diragukan lagi. Pada hakekatnya HAM merupakan satu kesatuan, namun kenyataan menunjukkan selama ini terdapat kesenjangan perhatian antara perlindungan terhadap hak sipil dan politik dengan perlindungan dan pemenuhan hak ekosob. Perlindungan dan pemenuhan hak ekosob menjadi kebutuhan penting bagi rakyat yang sesungguhnya juga sangat bergantung pada komitmen negara, yaitu adanya campur tangan dan peran negara yang lebih aktif.

Peluang-peluang hak klaim korban pelanggaran hak ekosob di Indonesia dalam perkembangannya bermunculan dan diakui keberadaannya. Adanya gugatan terhadap pemenuhan hak ekosob lebih berkaitan dengan dampak pembangunan dan kasus-kasus dalam industri perekonomian.

Hak atas lingkungan hidup yang baik dan sehat seperti halnya dengan hak-hak ekonomi, sosial dan budaya lainnya, dapat dibuktikan secara teoritis sebagai hak yang justiciable yaitu dapat dituntut pemenuhannya melalui pengadilan. Isu perlindungan dan penegakan hak atas lingkungan hidup yang baik dan sehat memiliki kualitas legal untuk dibawa ke muka lembaga peradilan (domestik, regional, ataupun internasional) untuk diperiksa dan diputus. Contohnya saja pada citizen law suit dalam perkara nomor 55/PDT.G/2013/PN.SMDA ${ }^{43}$ yang diajukan pada tanggal 25 Juni 2013 oleh warga Samarinda yang diputuskan oleh Majelis Hakim Pengadilan Negeri Samarinda. Majelis hakim dalam kasus ini memutuskan bahwa Para tergugat (dalam hal ini c.q walikota Samarinda, cq. Menteri Energi dan Sumber Daya Mineral (ESDM), cq. Gubernur Provinsi Kalimantan Timur, cq. Menteri Lingkungan Hidup RI, cq. DPRD Tingkat II Kota Samarinda) dinyatakan lalai dalam melaksanakan kewajibannya untuk menciptakan lingkungan hidup yang baik dan sehat, yang mengakibatkan kerugian kepentingan umum bagi warga negara khususnya bagi warga kota Samarinda dan merumuskan kembali kebijakan umum men-

40 Terkait dengan kerusakan hutan dan lahan di Indonesia terdapat perbedaan data yang disampaikan oleh berbagai sumber diantaranya FAO sebesar 1.315.000 hektar/ tahun atau 1 persen per tahun, data Green Peace kerusakan hutan di Indonesia sebesar 3.800.000 ha/tahun, dan Departemen Kehutanan 300.000 hektar/tahun.

41 Ben Boer, "Environmental Law and Human Rights in the Asia Pacific"dalam buku "Environmental Law Dimensions of Human Rights"diedit oleh Ben Boer, 2015, United Kingdom: Oxford University Press, h. 135.

42 Ibid.

43 Beberapa warga Samarinda yang didukung berbagai organisasi nonpemerintah mengajukan gugatan citizen law suit yang pertama kalinya di Samarinda. Penggugat menuntut perbaikan kondisi Samarinda yang dikuasai izin tambang yang carutmarut. Data menyebutkan bahwa sudah delapan anak tewas di kolam bekas tambang, 20.106 kepala keluarga menjadi korban banjir di 35 titik di Samarinda yang diperparah oleh karena aktivitas pertambangan. Belum lagi 63 IUP (27.555 hektar) dan lima perjanjian karya pengusahaan pertambangan batu bara (PKP2B) (24.039 hektar) yang diterbitkan pusat. Seluruh izin pertambangan di Samarinda mencapai 71 persen luas kota. Dampak lain yaitu telah terjadi peningkatan bayi yang meninggal dalam kandungan, penderita autisme, dan infeksi saluran pernapasan atas selama aktivitas pertambangan di Kota Tepian. Lihat http:// kaltim.prokal.co/read/news/85339-lsm-pukul-ko-pemerintah, diakses tanggal 17 Juli 2014. Lihat pula http://regional.kompas.com/ read/2014/07/17/07452001/Warga.Samarinda.Korban.Tambang.Menangkan.Gugatan.atas.Pemerintah, 
genai pertambangan batu bara yang meliputi evaluasi terhadap seluruh ijin pertambangan yang telah dikeluarkan, mengawasi pelaku usaha untuk merealisasikan reklamasi dan pasca tambang, perbaikan fungsi lingkungan hidup, melakukan upaya strategis dalam perlindungan kawasan pertanian dan perikanan masyarakat dari pencemaran berbagai akibat kegiatan pertambangan.

Preseden tersebut merupakan salah satu metode alternatif sebagai upaya hukum yang dilakukan oleh warga negara untuk menggugat pemerintah maupun korporasi demi memperbaiki tata kelola lingkungan agar kerusakan dan pencemaran lingkungan yang merugikan kepentingan publik tidak terulang. Penyelenggara negara memiliki mandat dan tanggung jawab untuk melakukan perlindungan, pemajuan, penegakan dan pemenuhan HAM.

Terkait dengan pemenuhan hak warga atas lingkungan hidup yang baik dan sehat, bencana kabut asap berikut penyebabnya telah berdampak pada terjadinya degradasi kondisi lingkungan hidup dan mengancam kondisi sosial, ekonomi dan kesehatan warga negara. Dalam hal ini terdapat tanggung jawab negara sebagaimana yang diperintahkan konstitusi untuk dijalankan. Hak atas lingkungan hidup yang baik dan sehat merupakan hak dasar, dimana negara berkepentingan untuk memastikan terwujudnya amanat konstitusi melindungi seluruh warga dan segenap tumpah darah Indonesia.

Dengan dasar tersebut di atas, citizen law suit terkait hak atas lingkungan hidup yang baik dan sehat dapat diajukan ke pengadilan. Bencana kabut asap yang terjadi rutin setiap tahun dan berulang kali terjadi selama belasan tahun di Indonesia ini mengabaikan hak warga untuk mendapatkan lingkungan bersih dan sehat. Bentuk pengabaiannya antara lain adalah tindakan yang diambil pemerintah cenderung insidental yaitu pembentukan satuan tugas penanganan bencana kabut asap untuk bekerja melakukan pemadaman kebakaran hutan dan lahan, baik melalui jalur darat maupun melalui operasi udara seperti water bombing. Anggaran penanganan dan penanggulangan kebakaran hutan dan lahan, pun sedikit sekali, dananya tidak mencapai 5 persen dari anggaran Kementerian Lingkungan Hidup, sehingga tidak sebanding untuk mengawal 120 juta hektar hutan di Indonesia. ${ }^{44}$

Dalam citizen law suit terkait hak atas lingkungan hidup yang baik dan sehat, seyogyanya warga juga menuntut evaluasi kebijakan dan aturan yang terkait dengan pengelolaan lingkungan hidup. Di tengah penolakan besar-besaran terhadap pembakaran hutan ternyata masih ada aturan yang memperbolehkan pembakaran lahan untuk perkebunan dengan batasan tertentu yaitu Peraturan Gubernur Kalimantan Tengah Nomor 15 Tahun 2010 Tentang Perubahan Peraturan Gubernur Kalimantan Tengah Nomor 52 Tahun 2008 Tentang Pedoman Pembukaan Lahan dan Pekarangan Bagi Masyarakat di Kalimantan.

Peraturan Gubernur yang mengizinkan masyarakat untuk membakar lahan tersebut merupakan problematika hukum yang diturunkan oleh aturan payung di atasnya yaitu Undang-Undang Nomor 32 Tahun 2009 tentang Pengelolaan dan Perlindungan Lingkungan Hidup (UU Perlindungan dan Pengelolaan Lingkungan Hidup) yang melarang pembakaran hutan dan bah-

44 Lihat “Walhi Kritik Minimnya Alokasi Dana Penanganan Kebakaran Hutan".http://www.cnnindonesia.com/ ekonomi/20150915133509-92-78849/walhi-kritik-minimnya-alokasi-dana-penanganan-kebakaran-hutan/. 


\section{KERTHA PATRIKA}

Volume 38, Nomor 1, Januari-April 2016

kan memberikan sanksi tegas kepada para pelanggarnya. Suatu catatan juga perlu diberikan karena bagianpenjelasan atas undang-undang tersebut justru memberikan pemakluman kepada masyarakat yang membakar hutan untuk keperluan buka lahan.

Pasal 69 ayat (1) huruf h UU Perlindungan dan Pengelolaan Lingkungan Hidup mengatur ketentuan larangan untuk melakukan pembukaan lahan dengan cara membakar. Namun dalam penjelasan atas ketentuan tersebut, keterangan yaitu dilakukan dengan memperhatikan dengan sungguh-sungguh kearifan lokal di daerah masing-masing. Kearifan lokal yang dimaksud dalam ketentuan tersebut adalah melakukan pembakaran lahan dengan luas lahan maksimal 2 hektar per kepala keluarga untuk ditanami tanaman jenis varietas lokal dan dikelilingi oleh sekat bakar sebagai pencegah penjalaran api ke wilayah sekelilingnya. Kearifan lokal inilah yang kemudian menjadi pasal pemakluman bagi masyarakat yang membakar hutan untuk membuka lahan. Ketentuan tersebut sejatinya harus dievaluasi dan direvisi karena menjadi ruang atau celah legalisasi pembakaran lahan yang pada akhirnya memberi dampak buruk bagi lingkungan dan manusia.

\section{Kesimpulan dan Saran}

\section{Kesimpulan}

Pemaparan di atas menunjukkan bahwa walaupun aturan mekanisme gugatan citizen law suit belum diatur di Indonesia, mekanisme ini sesungguhnya sangat diperlukan sebagai kontrol atas kebijakan pemerintah yang mengabaikan atau melanggar pemenuhan terhadap hak asasi manusia (HAM), khususnya hak ekonomi, sosial dan budaya (ekosob). Dalam perkembangan kehidupan bernegara tidak sedikit ditemui indikasi kelalaian ataupun pengabaian yang dilakukan otoritas pemerintah yang dapat merugikan warga negara. Rakyat sebagai pemegang kedaulatan seyogyanya memiliki ruang untuk menggugat pemerintah demi tercapainya keadilan. Dalam beberapa peraturan perundang-undanganpun telah diamanatkan perlindungan terhadap kepentingan warga negara. Justiciability hak ekosob pun sebenarnya tidak perlu diragukan lagi. Di tingkat pengaturan internasional, mekanisme resmi untuk prosedur komplain (complaint mechanism) hak ekosob memang belum secara rinci diatur, akan tetapi, kekosongan aturan ini telah ditutupi oleh kemajuan-kemajuan praktek mekanisme gugatan terhadap hak ekosob di tingkat regional. Salah satunya yaitu berupa praktek diajukannya gugatan citizen law suit untuk menuntut pemenuhan terhadap hak ekosob. Hak ekosob juga merupakan hak konstitusional warga dalam ranah perlindungan terhadap HAM. Untuk itu terdapat tugas dan tanggung jawab negara untuk mewujudkannya dan memberikan perlindungan. Di sisi lain, terdapat hak bagi warga negara untuk mendapatkan pemenuhan atas HAM yang dimilikinya beserta hak untuk mengajukan tuntutan/gugatan kepada negara melalui mekanisme yang sesuai.

\section{Saran}

Langkah yang perlu dirumuskan ke depan adalah peraturan perundang-undangan ataupun landasan hukum yang mengatur rinci mengenai mekanisme gugatan citizen law suit hendaknya segera dibentuk sehingga tercipta kepastian dan perlindungan hukum. 


\section{DAFTAR PUSTAKA}

\section{A. Buku}

Agustina, Rosa. 2003. Perbuatan Melawan Hukum. Program Pasca Sarjana Fakultas Hukum Universitas Indonesia, Jakarta.

Asshiddiqie, Jimly. 2010. Green Constitution. Rajawali Pers, Jakarta.

. 2012. Hukum Tata Negara dan Pilar-Pilar Demokrasi. Penerbit Sinar Grafika, Jakarta.

Berting, Jan, et.al. 1990. Human Rights in a Pluralist World: Individuals and Collectivities, First Edition, Meckler, London

Boer, Ben et.al. 2015. “Environmental Law Dimensions of Human Rights”, Oxford University Press

Fadjar, Mukthie. 2004. Tipe Negara Hukum, Bayu Media, Malang.

Garner, Bryan A., et.al (ed). 1999. Black’s Law Dictionary, St. Paul West Publishing Co.

Hackett, Steven C. 2011. Environmental and Natural Resources Economic: Theory, Policy, and the Sustainable Society, Fourth edition, Routledge Taylor and Francis Group, London \& New York.

Handoyo, Hestu Cipto. 2015. Hukum Tata Negara Indonesia, Cahaya Atma Pustaka, Yogyakarta.

International Commision of Jurist (ICJ). 2008. Courts and the Legal Enforcement of Economic, Social and Cultural Rights: Comparative Experiences of Justiciability, ICJ, Geneva.

Nasution, Adnan Buyung, et.al. Instrumen International Pokok Hak-hak Asasi Manusia, Edisi ke 2, Yayasan Obor Indonesia, Jakarta.

Mahkamah Agung RI . 2009. Laporan Penelitian Class action dan Citizan Lawsuit, Badan Penelitian, Pengembangan, Pendidikan dan Pelatihan Hukum dan Mahkamah Agung RI, Bogor.

Ranawijaya, Usep. 1983. Hukum Tata Negara, Dasar-Dasarnya,Ghalia Indonesia, Jakarta

Sundari, E. 2000. Pengajuan Gugatan Secara Class Action (Suatu Studi Perbandingan dan Penerapannya di Indonesia), Universitas Atma Jaya Yogyakarta, Yogyakarta.

Vasak, Karel. 1982. The International Dimensions of Human Rights, Volume 1, Greenwood Press and France: UNESCO, Connecticut.

\section{B. Jurnal/Makalah}

Fatah, Abdul. Gugatan Warga Negara Sebagai Mekanisme Pemenuhan Hak Asasi Manusia dan Hak Konstitusional Warga negara. Jurnal Yuridika, 2013, Vol. 28 No. 3.

Prasojo, Antonio. Membela Hak Asasi Ekonomi dan Sosial. Jurnal HAM. 2003, Vol. 1 No.1. 


\section{KERTHA PATRIKA}

Volume 38, Nomor 1, Januari-April 2016

Verma, Shivani. 2005.“Justiciability of Economic Social and Cultural Rights (Relevant Case Law)”, Makalah dalam The International Council on Human Rights Policy Review Meeting, Geneva.

\section{Internet}

"Indonesia Kabut Asap“.http://www.bbc.com/, diakses 15 Oktober 2015

"Walhi Kritik Minimnya Alokasi Dana Penanganan Kebakaran Hutan”.http://www.cnnindonesia.com/, diakses

"Gugatan Cls Kenaikan Harga BBM Kandas Karenan Notifikasi”.http://www.hukumonline.com/, diakses 14 Februari 2014

“LSM Pukul KO Pemerintah”.http://kaltim.prokal.co/, diakses 17 Juli 2014

"Dampak Kabut Asap Ispa Jangkiti 425 Ribu Jiwa di 7 Provinsi”. http://nasional.tempo.co/, diakses 17 Oktober 2015

"Warga Samarinda Korban Tambang Menangkan Gugatan atas Pemerintah, http://regional.kompas.com/, diakses 17 Agustus 2014

http://www.ohchr.org/EN/Issues/ESCR/Pages/CanESCRbelitigatedatcourts.aspx.

https://treaties.un.org/Pages/ViewDetails.aspx?src=TREATY\&mtdsg_no=IV-3\&chapter=4\&lang=en

\section{Konvensi Internasional/Peraturan Perundang-undangan}

Undang-Undang Dasar Negara Republik Indonesia 1945

Undang-Undang Nomor 39 tahun 1999 tentang Hak Asasi Manusia (Lembaran Negara Republik Indonesia Tahun 1999 Nomor 165, Tambahan Lembaran Negara Republik Indonesia Nomor 3886)

Undang-Undang Nomor 32 tahun 2009 tentang Perlindungan dan Pengelolaan Lingkungan Hidup(Lembaran Negara Republik Indonesia Tahun 2009 Nomor 140, Tambahan Lembaran Negara Republik Indonesia Nomor 5059)

International Covenant on Economic, Social and Cultural Rights (ICESCR)

International Covenant on Civil and Politic Rights (ICCPR)

\section{E. Kasus Hukum}

MC Mehta v. Union Of India, AIR 1998 SC 10 37. Gangga Pollution (Tanneries) Case

MC Mehta v. Union Of India, AIR 1998 SC 11 15. Gangga Pollution (Municipalities) Case

48 Jurnal Ilmiah Fakultas Hukum Universitas Udayana 